\title{
Ortaokul Öğretmenlerinin Örgütsel Adalet Algı Düzeyleri İle Örgütsel Mutluluk Düzeyleri Arasındaki İlişki ${ }^{1}$
}

\author{
Serkan ÇETIN ${ }^{2}$ ve Soner POLAT ${ }^{3}$
}

\section{Öz}

$\mathrm{Bu}$ araştırmada, ortaokul öğretmenlerinin örgütsel adalet alg1 düzeyleri ile örgütsel mutluluk düzeyleri arasındaki ilişkinin ortaya konulması amaçlanmıştır. Araştırmada ilişkisel tarama modeli kullanılmıştır. Araştırmanın evrenini Kocaeli İli İzmit İlçe merkezindeki ortaokullardaki öğretmenler oluşturmaktadır. Araştırmanın örneklemini ise, 20182019 Eğitim-Öğretim yllında Kocaeli ili merkez İzmit ilçesinde bulunan genel ortaokulları ile imam-hatip ortaokullarında görev yapan 533 ögrretmen oluşturmaktadır. Veri toplama araçları olarak, Niehoff ve Moorman tarafindan geliştirilen ve Polat (2007) tarafindan Türkçe'ye uyarlanan 'Örgütsel Adalet Ölçeği” ile Paschoal ve Tamayo tarafindan geliştirilen, Arslan ve Polat (2018) tarafından Türkçe’ye uyarlanan "Örgütsel Mutluluk Ölçeği”" kullanılmıştır. Verilerin analizinde; değişkenler arasındaki korelasyon için Pearson korelasyon katsayısı hesaplanmış, yordayıcı değişkenlerin yordanan değişkeni yordama gücünü incelemek için de önce basit doğrusal regresyon analizi, sonrasında çoklu doğrusal ve çoklu hiyerarşik regresyon analizleri yapılmıştır. Araştırma bulguları, öğretmenlerin örgütsel adalet alg1 düzeylerinin örgütsel mutluluk düzeylerini anlamlı biçimde yordadığını ortaya koymaktadır. Araştırma sonuçları, örgütsel adaletin alt boyutları özelinde incelendiğinde etkileşimsel adalet ve işlemsel adalet alt boyutlarının örgütsel mutluluğun anlamlı birer yordayıcısı olduğu ancak etkileşimsel adalet alt boyutunun örgütsel mutluluğu anlamlı biçimde yordamadığını göstermektedir. Araştırma sonucunda elde edilen bulgular öğretmenlerin örgütsel adalet alg1 düzeylerinin yükseltilmesine yönelik çalışmaların öğretmenlerin örgütsel mutluluk düzeylerinin artırılmasına katkı sağlayacağını göstermektedir.

Anabtar Kelimeler: Örgütsel Adalet, Örgütsel Mutluluk, Ortaokul, Öğretmen

The Relationship between Secondary School Teachers' Organizational Justice Perception Levels and Organizational Happiness Levels

\begin{abstract}
This study is aimed to reveal the relationship between secondary school teachers' organizational justice perception levels and organizational happiness levels. The relational scanning model was used in the research. The universe of the study consists of teachers in secondary schools in Izmit District Center of Kocaeli Province. The sample of the study consists of 533 teachers working in General Secondary Schools and Religious Secondary Schools in Izmit district of Kocaeli province in 2018-2019 academic year. As data collection tools, the "Organizational Justice Scale" developed by Niehoff and Moorman and adapted to Turkish by Polat (2007) and the "Organizational Happiness Scale" developed by Paschoal and Tamayo and adapted into Turkish by Arslan and Polat (2018) were used. In the analysis of the data, the Pearson correlation coefficient was calculated for the correlation between variables, and to examine the predictive power of the predictive variables on the predicted variable, first simple linear regression analysis, then multiple linear and multiple hierarchical regression analyzes were done. Research findings reveal that teachers' perceptions of organizational justice significantly predicted their organizational happiness levels. The results of the research show that when the sub-dimensions of organizational justice are examined, the interactional justice and procedural justice sub-dimensions are significant predictors of organizational happiness, but the interactional justice sub-dimension does not significantly predict organizational happiness. The findings obtained as a result of the research show that the studies aimed at increasing the organizational justice perception levels of the teachers will contribute to the increase of the organizational happiness levels of the teachers.
\end{abstract}

Key Words: Organizational Justice, Organizational Happiness, Middle School, Teacher

\section{Atıf İçin / Please Cite As:}

Çetin, S. ve Polat, S. (2021). Ortaokul öğretmenlerinin örgütsel adalet alg1 düzeyleri ile örgütsel mutluluk düzeyleri arasındaki ilişki. Manas Sosyal Araştırmalar Dergisi, 10(1), 171-182.

Geliş Tarihi / Received Date: 25.09.2020

Kabul Tarihi / Accepted Date: 04.12.2020

\footnotetext{
1 Bu makale Kocaeli Üniversitesi Sosyal Bilimler Enstitüsü’nde ikinci yazarın danışmanlığında yürütülen aynı konulu yüksek lisans tezinden üretilmiştir.

2 Öğretmen - Kocaeli İzmit Milli Eğitim Müdürlüğü, serkancetin98@yahoo.com - (D ORCID: 0000-0003-0299-0813

3 Prof. Dr. - Kocaeli Üniversitesi Eğitim Fakültesi, spolat@kocaeli.edu.tr - ID ORCID: 0000-0003-2407-6491
} 


\section{Giriş}

İnsanların sahip olduğu temel hedeflerden birisi kuşkusuz mutlu olmaktır. Araştırmalar, mutlu olmanın; iyi hissetmenin ve keyifli bir yaşam sürmenin; bireye ve bireyin parçası olduğu örgüte pek çok avantaj sağladığını da göstermektedir. Okullar, toplumsal dönüşümün başladığı örgütler olduğundan toplumun alt sistemlerinden biri olan okulu etkileyecek her türlü değişim toplumu da etkilemektedir. Şüphesiz okul örgütlerinin iş görenleri olan öğretmenlerin mutlu olması öğrencilerin de mutlu olmasina katkı sağlayacaktır.

İş görenler bir örgüte dahil olduklarında kendilerinde var olan bilgi ve tecrübelerini sermaye olarak yanlarına alırlar. Bu sermayelerini zamanla örgütün çıkarları adına kullanmaya başlayarak bireysel faydaları için emeklerini yatırıma dönüştürme gayretine girerler ve örgüte verdikleri fayda oranında eşit (ücret, terfi, tanınma vb.) çıktı sağlamayı arzu ederler. Sonrasında elde edilen çıktıları kendilerine bir ölçüt alarak, diğer iş görenlerin edinimleriyle kendi kazanımlarını kıyaslarlar. Bu kıyaslamayı yaparken, kendilerince bazı adalet değerlendirmeleri yaparlar. Bu kıyaslama, kişilerin örgüt içerisinde şahsına adil davranılıp davranılmadığına ilişkin algısını oluşturur. Adalet alg1sı yüksek olan bireyler; örgütün sağlıklı bir çalışma ortamına dönüşmesine, örgüt faaliyetlerinin daha etkin bir biçimde gerçekleştirilmesine katkı sağlayacaklardır. Bu çalısmada öğretmenlerin örgütsel adalet ve alt boyutlarına dair algı düzeyleri ile örgütsel mutluluk düzeyleri arasındaki ilişkiye odaklanılmışır.

\section{Kavramsal Çerçeve}

\section{Örgütsel Adalet ve Boyutları}

Adalet kavramı, insanlık tarihi boyunca insanların basit ve doğal bir ihtiyacı olarak toplulukların gelişebilmesi için ihtiyaç duyduğu uygun zemini hazırlamışıtır (Yaghubi vd., 2009, s. 25). Yıllar önce sosyal bilimler uzmanları örgütsel sürecin etkinliği için gerekli ve radikal bir dayanak olarak örgütsel adaletin önemini ortaya koymuşlardır (Barati, Arizi ve Noory, 2009, s. 10). İlk olarak örgütsel adalet kavramı 1961 yllında Homans tarafindan kullanılmıştır. Örgütsel adalet üzerine yapılan erken dönem çalışmalarda işgörenlerin algisı (sonuç) ve bu sonuçlara götüren süreç (işlemler) üzerine yoğunlaşılmışır (Cropanzano ve Greenberg, 1997, s. 369).

Greenberg (1996, s. 24) örgütsel adaleti, işgörenlerin örgütlerin bazı işleyiş ve uygulamalarını algılayış şekli olarak değerlendirmiştir. Cropanzano, Bowen ve Gilliand (2007, s. 35) ise örgütsel adaleti işgörenlerin etik ve ahlaki kapsam dâhilinde idarecilerini bireysel olarak değerlendirmeleri olarak ifade etmisslerdir.

Örgütsel adalet kavramının işgörenler için önemli olması iki farklı başlık altında değerlendirilmiştir. Öncelikli olarak adalet, işgörenlere kazanımlarını arttırabilme imkânını sağlamaktadır. Bunun neticesinde işgörenler uzun vadeli kazanımlarını artırmak için kısa süreli kazançlarını göz ardı edebilmektedir. Bu anlayış "Kişisel Çıkar Modeli" şeklinde de değerlendirilmektedir (İçerli, 2010, s. 70). Diğer önemli neden ise, adalet her koşulda kıymetli bir kavramdır ve bireyler için bir anlam ifade eder. Çünkü sosyal ortam içinde saygınlık sağlar ve işgören kendini daha itibarlı hisseder. Aynı zamanda işgören ortamın değişmez bir değeri olduğunu hissetmesi nedeniyle daha ileri performansla çalışır. Ayrıca bu şekilde mevcut ortamda bireysel statüsünü yükseltmiş olur. Bu anlayış, "Grup Değeri Modeli” şeklinde ifade edilir ve daha fazla psikolojik etkiler meydana getirir (Cropanzano vd., 2001, s. 63; İçerli 2010, s. 70).

Örgütsel adaletin kapsamı konusunda öne ç1kan kavramlar, örgütsel kararlar ve yönetici pozisyonundaki birey ya da bireylerin tutum ve eylemleridir (Yeniçeri, Demirel ve Seçkin, 2009, s. 96). Bu noktada işgörenlerin beklentisi; kararlar alınırken adil bir tutum sergilenmesi olacaktır. Örgütte bütün işgörenlerin örgütsel adalet algılarını etkileyecek başlıca yönetici prensipleri; doğruluk, dürüstlük, meslek ahlakına yaraşır davranma, tutarlılık, ön yargılı olmama, karşı görüşe saygı duyma, esnek davranabilme ve ortak karar alma şeklinde sayılır (Eren, 2000, s. 553). Örgüt içerinde adaletin sağlanamaması çeşitli olumsuz sonuçlar ortaya çıkarabilir. Bu istenmeyen durumlardan bazıları; "saldırgan olma, örgütten çalma, tutarlı davranmama, eşit olmama, meslek etiğine uygun davranmama, yolsuzluk ve sorumlukların adil dağıtılmaması" biçiminde ifade edilebilir (Özmen, Arbak ve Özer, 2007, s. 20).

Araştırmacılar başlarda örgütsel adaleti iki başlık altında incelemişlerdir. Bunlar işlemsel adalet ve dağıtımsal adalettir. İlişkisel ve iki yapılı modeli destekleyenler, işlemsel ve etkileşimsel adaleti çıktı ve işlem ikilisi ile aynı kapsamda değerlendirmişlerdir (Lind ve Taylor, 1988). Bies ise örgütsel adaleti üç boyutta ele almıştır. Bu model günümüzde örgütsel adalet için en çok kullanılan model olmakla birlikte bazı araştırmalarda etkileşimsel adalet hala üçüncü bir boyut olarak kabul edilmeyip işlemsel adaletin alt bileşeni 
olarak değerlendirilmektedir (Masterson, vd. 2000, s. 739). Colquitt ve arkadaşlarının (2001) yaptı̆ğ çalışmada örgütsel adalet; dağıtımsal, işlemsel ve etkileşimsel adalet boyutları ile ele alınmış ve en kabul gören örgütsel adalet sınıflamasından biri olmuştur.

1975 yllından günümüze adalet ile ilgili çalışmalar incelendiğinde dağıtımsal adaletin ön plana çıktığı görülmektedir (Colquitt, vd. 2001, s. 426). Dağıtımsal adalet, örgüt içinde ödül ve ceza gibi yaptırımların adil bir şekilde dağıtıllması anlamına gelir. Dağıtımsal adalet belirli bir davranışı gösteren işgörenlerin belli kazanımları adil bir şekilde elde edeceğini ifade eder (İşcan ve Naktiyok, 2004, s. 183). Dolasıyla sonuçların adil olarak algilanmasiyla ilgilidir.

İşlemsel adalet, kazanımların ne şekilde dağılacağı konusunda belirlenen yöntemlerin adil olarak kullanılması gerektiğini açıklar (Beugre, 2001, s. 1095). İşlemsel adalet; işgörenler için büyük önem taşıyan terfi, ücret, performans değerlendirme ve çalışma şartları gibi konularla ilgili hususların tespitinde kullanılan yöntem ve politikaların adil olma derecesini ifade eder (Tan ve Çetin, 2011, s. 2).

Etkileşimsel adalet, yöneticilerin örgüt içerisinde karar alınmasına ilişkin yaşanan süreçleri, işgörenlere açık, şeffaf ve dürüst bir biçimde açıklaması şeklinde tanımlanır (İçerli, 2010, s. 86). Yine etkileşimsel adalet, örgütteki yöntem ve işlemler sırasında işgörenlerin karşılaştığı tutum ve davranışların kalitesine ait adalet algisı şeklinde de ifade edilir (Bies ve Moag, 1986, s. 50). Etkileşimsel adalet, dağıtımsal ve işlemsel adalet boyutlarından farklı olarak elde edilen maddi veya manevi kazanımlarla değil karşıılılı etkileşim sırasında ortaya konan empati yapma, sosyal duyarllığa sahip olma, saygilı davranma gibi değerlerle de ilgilidir (Demirel ve Seçkin, 2011, s. 103).

\section{Örgütsel Mutluluk ve Boyutları}

Mutluluk, öznel iyi olma hali şeklinde tanımlanmaktadır. Bu nedenle bireysel bir kavram olduğu gibi, sosyal ve kişiler arası ilişkiler ile örgütsel bağlamdan da etkilenen bir kavram olarak ele alınmaktadır (Arslan, 2018, s. 55). Örgütsel mutluluk; bireyin performansını yükselten ve onun potansiyelini ortaya çıkarmak için bireyi harekete geçiren bir zihin yapısıdır. Bireyler mutluluğa, tek başına veya başkalarıyla etkileşirken farkına vararak ulaşmaktadır (Pryice-Jones, 2011). Ayrıca bireyler mutluluklarını artırmak için daha iyi şartlara sahip örgütlerde çalışmak istemektedir (Gavin ve Mason, 2004, s. 381-387). Görüldügü üzere bireyin çalıştı̆̆ örgütteki örgütsel mutluluk alg1s1, bireylerin bütünsel mutluluk düzeylerini artırmada önemli katk1lar sunabilir (Frey ve Stutzer, 2001, s. 29).

Warr (2011) insanların parçası oldukları örgütlerde birçok farklı duygu durumunu tecrübe ettiği ve bu tecrübelerin bireylerin potansiyelini gerçekleştirmeleri ve dolayısıyla hedefledikleri mutluluğa ulaşmalarını etkilediklerini ifade eder. Örgütsel mutluluğun bireyin toplam mutluluğuna etkisi bakımından önemi yapılan birçok çalışma ile ortaya konmasına rağmen çoğu örgüt bireylerin mutlu olmalarına yönelik olarak tasarlanmamaktadır (Csikszentmihalyi, 2005, s. 29).

Örgütsel alanyazın incelendiğinde örgütsel mutluluk kavramı, duygusal, bilişsel ve potansiyeli gerçekleştirme kavramları ile birlikte tanımlanmaktadır. Duygusal yaklaşımı savunan araştırmacılar, örgütsel mutluluğu örgüt içerisinde ortaya çıkan tüm duyguların birleşimi şeklinde tanımlayarak sadece duygu durumuna odaklanır (Daniels, 2000). Waterman (1993) ise örgütlerde işgörenlerin potansiyellerini gerçekleștirme becerilerinin ve etkilerinin, duygularla bir araya gelerek örgütsel mutluluğu oluşturduğunu savunmaktadir.

Bradburn araştırmalarında (Bradburn 1969; Bradburn ve Caplovitz 1965) mutlu olmanın öncelikli iki yapısı olarak kabul edilen olumlu ve olumsuz duyguyu ele alınmıştır. Mutluluğun iki faktörden (olumlu duygu ve olumsuz duygu) oluştuğunu ve kişilerin olumsuz duygularıyla olumlu duygularını kıyaslayarak elde ettikleri genel bir değerlendirme olduğunu ifade etmiştir (Diener, 1984, s. 547). Mutluluğun değerli bir bileşeni olarak kabul edilen potansiyelin gerçekleştirilmesi terimi öncelikle Neugarten, Havighurstve Tobin (1961) tarafından kullanılmışır. Tanımına göre bir bireyin arzuları ile elde ettiklerinin kıyaslanmasıyla oluşan bireyin beklentilerine ulaşmadaki algısal değerlendirmesidir.

Olumlu duygular; kişiyi mutlu eden duygulardır ve umut, neşe, sevinç, memnuniyet, gurur, huzur, ilgi gibi kavramlarla ortaya çıkar (Bulut, 2015, s. 23- 24). Olumlu duyguların varlı̆̆ kişide memnuniyet hissine sebebiyet verir ve bu his yüksek derece mutluluk yaşandığının göstergesi olarak ifade edilir (Warr, 2011). Okul örgütlerinde görev yapan öğretmenler açısından olumlu olarak kastedilen duygular; mutlu, keyifli, işine karşı arzulu, istekli ve memnun ve aktif olma olarak sıralanabilir (Arslan, 2018, s. 59). 
Olumlu duyguların zıttı olarak ifade edilen bu duygular kişileri mutsuz eder. Olumsuz duygulara; üzüntü, stres, sıkıntı, kızgınlık, kıskançlık gibi örnekler verilebilir (Bulut, 2015, s. 24). Olumsuz duygular yaşayan insanlar memnuniyetsizlik hissine kapılır (Diener, 2000, s. 34). Bu memnuniyetsizlik hissi, aşırı endişe ve depresif modlar ile mutsuzluğun göstergeleridir (Warr, 2011). Okul örgütlerinde görev yapan öğretmenler açısından olumsuz olarak kastedilen duygular; gergin, sinirli, sabırsız, kaygılı, depresif, üzgün olarak sayllabilir (Arslan, 2018, s. 60).

Potansiyeli gerçekleştirme boyutu; olumlu duygular ve olumsuz duygular boyutlarından farklı olarak örgütsel mutluluğun bilişsel yönü ile ilgilidir. Bu boyut; bireyin kendi özelliklerini tanıyarak geliştirmesi, potansiyelini fark ederek onu gerçekleştirmesi şeklinde tanımlanır (Warr, 2011). Kişinin sahip olduğu yetenekleri ve potansiyeli gösterebileceği çalışmalarda bulunması (Kashdan, Biswas-Diener ve King, 2008, s. 219), işinde sahip olduğu becerilerden farklı beceriler kazanma imkânı (Warr, 2011, s. 154), işinden keyif almas1 (Bakker ve Demerouti, 2013) ve performansını arttırabilmesi (Golparvar ve Abedini, 2014, s. 255) potansiyelin gerçekleştirilmesi boyutuyla ilişkili kavramlar olarak sayılabilir.

\section{Örgütsel Adalet ile Örgütsel Mutluluk Arasındaki İlişki}

İşgörenlerin örgütsel mutluluk düzeyleri birçok değişkenden etkilenmektedir. Bu değişkenler örgüt dışından olabileceği gibi örgüt içerisinden de olabilir. Örgüt içerisindeki uygulamalar ile bu uygulamaların örgütün üyeleri tarafindan algilanma biçimleri, örgütsel mutluluğu etkilemektedir (Fisher, 2010, s. 27). İşyerinde mutlu olma, temelde işgörenlerin örgütlerinde kaliteli bireysel deneyim yaşama firsatı bulması ile açıklanabilir (Grant ve Campbell, 2007, s. 671). Yönetimsel kararlar ve uygulamaların örgütsel mutluluğa önemli etkisinin olduğu ileri sürülmektedir (What Works Centre for Wellbeing, 2017, s. 16).

Bireyin örgüt içerisindeki faaliyetlere karşı adalet algisı olumlu ise, bireyin örgüte olan katkısı devam edecektir. Aksi durumda ise birey psikolojik bir çöküş yaşayarak hem örgütsel hem de bireysel olarak mutsuzluk yaşayacaktır (Bulut, 2015). Tezcan Uysal ve Aydemir (2014, s. 1569) örgütsel iklimin çalışma psikolojisine etkisi üzerine yaptıkları çalışmada, örgüt içerisinde bazı işgörenlere yönelik kayırma ya da ihtimaslı davranma gibi adil olmayan yönetici davranışlarının işgörenler arasındaki çatışma duygusunu tetiklediğini ve bu durumun işgörenlerin psikolojileri üzerine olumsuz etkilere sebep olduğunu ortaya koymuştur. Bu durum kaçınılmaz olarak örgütsel mutluluğu da olumsuz yönde etkileyecektir.

Jandaghi ve diğerlerinin (2012) ve Behrani’nin (2017) yaptıkları araştırmalarda örgütsel adalet ve alt boyutları ile örgütsel mutluluk arasında olumlu ve anlamlı bir ilişki olduğu bulunmuştur. Bir diğer araştırmada ise İşgörenlerin adalet algılarının psikolojik sermayeleri ve örgütsel mutlulukları üzerine etkisini ortaya koymak üzere yapılan araştırmada örgütsel adaletin işgörenlerin örgütsel mutluluk düzeylerini olumlu ve anlamlı bir şekilde etkilediği ortaya konmuştur (Çelik, Turunç ve Bilgin, 2014, s. 577). Bu sonuçlar alanyazında (Rani vd., 2012; Greenberg ve Colquitt, 2005; Walumbwa, Peterson, Avolio ve Hartnell, 2010) dile getirilen adil bir şekilde davranılan işgörenlerin kendilerini daha iyi hissettikleri ve psikolojik sermayelerinde artış olduğu hipotezini desteklemektedir.

\section{Araştırmanın amacı}

Araştırmanın amacı, ortaokullarda görev yapan öğretmenlerin örgütsel adalet alg1 düzeyleri ile örgütsel mutluluk düzeyleri arasındaki ilişkiyi ortaya koymaktır.

\section{Yöntem}

\section{Araştırmanın modeli}

$\mathrm{Bu}$ araştırmada ortaokullarda görev yapan öğretmenlerin örgütsel adalet alg1 düzeyleri ile örgütsel mutluluk düzeyleri arasındaki ilişki ortaya konulmaya çalışılmıştır. Bu nedenle araştırma nicel araştırma yöntemlerinden biri olan ilişkisel tarama modeli ile tasarlanmıştır. İlişkisel tarama modeli, iki veya daha fazla değişkenin birlikte bir değişim içerisinde olma durumunu ve derecesini belirlemeyi amaçlayan bir modeldir (Büyüköztürk, Kıllı̧-Çakmak, Akgün, Karadeniz ve Demirel, 2012, s. 23).

\section{Evren ve örneklem}

Çalışmanın evrenini 2018-2019 eğitim-öğretim yllında Kocaeli ili merkez İzmit ilçesindeki 6 imam hatip ortaokulu ile 41 genel ortaokulda görev yapan toplam 1092 öğretmen oluşturmaktadır. Belirlenen evren içerisindeki altı imam-hatip ortaokulun tamamına erişilmiş olup bu okullardaki öğretmenler örneklem grubuna dahil edilmiştir. Daha sonra evreni oluşturan genel ortaokullardan uygun örnekleme yoluyla öğretmenler seçilerek örneklem grubu tamamlanmıştır. Uygun örnekleme ismi ile de anılan elverişli 
örnekleme yönteminde zaman, para ve iş gücü kaybını önlemeyi temel amaç edinir (Büyüköztürk vd., 2016). Yazıcıŏ̆lu ve Erdoğan'ın (2004) örneklem hesaplama yöntemine göre araştırma evrenini \%97 güven aralığında temsil edecek minimum örneklem büyüklüğ̈ 516 olarak bulunmuştur.

Araştırmaya katılan öğretmenlere ait demografik özellikler Tablo 6'da sunulmuştur. Tablo 1 incelendiğinde araştırmanın katılımcıların \%67.4'ünün kadın (359), \%32.6'sının ise erkek (174) olduğu görülmektedir.

Tablo 1. Örneklemin Demografik Özellikleri

\begin{tabular}{llcc}
\hline & \multicolumn{1}{c}{ Demografik Özellik } & $\boldsymbol{n}$ & $\boldsymbol{\%}$ \\
\hline \multirow{2}{*}{ Cinsiyet } & Kadın & 359 & 67.4 \\
& Erkek & 174 & 32.6 \\
\multirow{3}{*}{ Doğum Yllı } & $1945-1964$ & 27 & 5.1 \\
& $1965-1980$ & 207 & 38.8 \\
& $1981-2000$ & 299 & 56.1 \\
\multirow{2}{*}{ Mesleki Kidem } & $1-10$ & 198 & 37.1 \\
& $11-20$ & 225 & 42.2 \\
& $21-30$ & 83 & 15.6 \\
Okul Türü & 31 ve üstü & 27 & 5.1 \\
& Genel Ortaokul & 422 & 79.2 \\
& İmam Hatip Ortaokulu & 111 & 20.8 \\
Okuldaki Hizmet Süresi & 1 Yildan Az & 97 & 18.2 \\
& $1-5$ & 268 & 50.3 \\
& 6-10 & 122 & 22.9 \\
\hline
\end{tabular}

Tablo 1'den anlaşlacağı üzere araştırmaya katılan öğretmenlerin doğum tarihlerinin \%5.1'inin (27) 1945-1964, \%38.8’inin (207) 1965-1980, \%56.1'inin (299) 1981 - 2000 aralıklarında olduğu görülmektedir. Yine ögrretmenlerin \%37.1'inin (198) 1-10 yıllık, \%42.2'sinin (225) 11-20 y1llık, \%15.6'sının (83) 21-30 ylllk ve \%5.1'inin (27) 31 yıl ve üstü kıdeme sahip oldukları görülmüştür. Ayrıca öğretmenlerin \%79.2'sinin (422) genel ortaokullarda, \%20.64'ünün (111) imam-hatip ortaokullarında görev yaptıkları Tablo 6'da sergilenmektedir. Son olarak araştırmaya katılanların okuldaki hizmet sürelerinin \%18.2'sinin (97) 1 yıldan az, \%50.3'ünün (268) 1-5 yll, \%22.9'unun (122) 6-10 yll, \%8.6'sının (46) 10 ylldan çok olduğu görülmektedir.

\section{Veri toplama araçları}

Araştırmada; öğretmenlerin örgütsel adalet alg1 düzeylerini ölçmek için "'Örgütsel Adalet Ölçeği", öğretmenlerin örgütsel mutluluk düzeylerini ölçmek için "Örgütsel Mutluluk Ölçeği" kullanılmıştır. Kullanılan ölçekler beşli likert tipindir.

Örgütsel Adalet Ölçeği (ÖÄ̈). Niehoff ve Moorman (1993) tarafindan geliştirilen bir ölçektir. ÖAÖ, dağtımsal adalet, işlemsel adalet ve etkileşimsel adalet şeklinde ifade edilen üç boyut ve 19 maddeden oluşmaktadır. Bu 19 maddenin 6'sı dağıtımsal adalet, 9'u işlemsel adalet ve 4'ü ise etkileşimsel adalet boyutlarına aittir. ÖAÖ, Polat (2007) tarafından '"Ortaöğretim Öğretmenlerinin Örgütsel Adalet Algıları, Örgütsel Güven Düzeyleri ile Örgütsel Vatandaşlık Davranışları Arasındaki İlişki” çalışması ile Türkçe'ye uyarlanan Ölçeğin Cronbach alfa katsayısıları ( $\alpha$ ); ölçeğin tamamı için 0.96 , dağıtımsal adalet boyutu için 0.89 , işlemsel adalet boyutu için 0.95 ve etkileșimsel adalet boyutu için 0.90 olarak hesaplanmıştır (Polat, 2007, s. 94). Bu çalışma da ise ölçeğin Cronbach alfa katsayıları ( $\alpha$ ); ölçeğin tamamı için 0.97, dağıtımsal adalet boyutu için 0.91, işlemsel adalet boyutu için 0.95 ve etkileşimsel adalet boyutu için 0.90 olarak hesaplanmıştır. Örgütsel adalet ölçeğine ilişkin Polat (2007) çalışmasındaki Cronbach's Alpha Katsayıları ile bu araştırmanın Cronbach's Alpha Katsayılarının tutarlı olduğu görülmüsşür.

Örgütsel Mutluluk Ölçeği (ÖMÖ). Demo ve Paschoal (2013) tarafindan geliştirilen ÖMÖ, üç boyut ve 29 maddeden oluşmaktadır. ÖMÖ'nün 9 maddesi olumlu duygular, 12 maddesi olumsuz duygular ve 8 maddesi de ise potansiyelin gerçekleştirilmesi boyutunda yer almaktadır. ÖMÖ’nün Türkçe’ye Uyarlanması" Arslan ve Polat (2018) tarafindan yapılmıştır. Ölçek olumlu duygular, olumsuz duygular ve potansiyelini gerçekleştirme olmak üzere 3 boyut ve 29 maddeden oluşmaktadır. Bu 29 maddenin 9'u duygular boyutunu, 12'si olumsuz duygular boyutunu ve 8'i ise potansiyelini gerçekleştirme 
boyutunu ölçmektedir. Ölçeğin Cronbach alfa katsayısıları ( $\alpha$ ); ölçeğin tamamı için 0.96, olumlu duygular boyutu için 0.94 , olumsuz duygular boyutu için 0.95 ve potansiyelini gerçekleştirme boyutu için ise 0.92 olarak bulunmuştur (Arslan ve Polat, 2017). Bu çalışmada ise . Ölçeğin Cronbach alfa katsayısıları $(\alpha)$; ölçeğin tamamı için 0.96, olumlu duygular boyutu için 0.91, olumsuz duygular boyutu için 0.94 ve potansiyelini gerçekleştirme boyutu için ise 0.93 olarak bulunmuştur. ÖMÖ'ye ilişkin Arslan ve Polat (2017) çalışmasındaki Cronbach’s Alpha Katsayıları ile bu araştırmanın Cronbach's Alpha Katsayılarının tutarlı olduğu görülmüştür.

\section{Verilerin Toplanması ve Analizi}

Verilerde yaşanması muhtemel kayıplar da düşünülerek toplam 800 veri toplama aracı dağıtılmıştır. Dağıtılan 800 ölçekten 625 tanesi öğretmenler tarafindan doldurulmuş, öğretmenler tarafindan eksik veya yanlış doldurulan, hiç doldurulmayan veri toplama araçları çıkartılarak (92 adet) 6 imam-hatip ortaokulundan 111, 19 genel ortaokuldan 422 ögretmen olmak üzere toplam 533 öğretmenden toplanan verinin analizi yapılmıstır.

Örgütsel adalet alg1 düzeylerinin yanı sıra boyutlarının her birinin de örgütsel mutluluk düzeyleri ile ilişkileri korelasyon analizinden, bu boyutların örgütsel mutluluğa etkisi regresyon analizinden yararlanarak hesaplanmıştır. Korelayon katsayısının .10 $\leq \mathrm{r}<.30$ olması düşük ilişkiyi, $.30 \leq \mathrm{r}<.50$ olması orta ilişkiyi, $\mathrm{r} \geq .50$ olması yüksek ilişkinin varlığını göstermektedir (Field, 2013).

\section{Bulgular}

Araştırmanın değişkenleri arasındaki ilişkileri ortaya koymak amacıyla Pearson korelasyon katsayıları hesaplanmıştır. Bu amaçla örgütsel adalet, dağıtımsal adalet, işlemsel adalet, etkileşimsel adalet, örgütsel mutluluk, olumlu duygular, olumsuz duygular ve potansiyelin gerçekleştirilmesi değişkenleri arasındaki ilişkiler Pearson korelasyon katsayısı hesaplanmış ve Tablo 2'de gösterilmiştir.

Tablo 2. Pearson Korelasyon Analizi Sonuclar

\begin{tabular}{|c|c|c|c|c|c|c|c|}
\hline & 2 & 3 & 4 & 5 & 6 & 7 & 8 \\
\hline 1. Örgütsel Adalet & $.96^{* *}$ & $.98^{* *}$ & $.92 * *$ & $.50^{* *}$ & $.51 * *$ & $.44^{* *}$ & $.34 * *$ \\
\hline 2. Dağıtımsal Adalet & & $.89 * *$ & $.85^{* *}$ & $.48^{* *}$ & $.49^{* *}$ & $.42^{* *}$ & $.31 * *$ \\
\hline 3. İşlemsel Adalet & & & $.85^{* *}$ & $.49 * *$ & $.50 * *$ & $.43^{* *}$ & $.35^{* *}$ \\
\hline 4. Etkileşimsel Adalet & & & & $.45^{* *}$ & $.45^{* *}$ & $.40^{* *}$ & $.30 * *$ \\
\hline 5. Örgütsel Mutluluk & & & & & $.91 * *$ & $.95^{* *}$ & $.62 * *$ \\
\hline 6. Olumlu Duygular & & & & & & $.74 * *$ & $.69 * *$ \\
\hline 7. Olumsuz Duygular* & & & & & & & $.50 * *$ \\
\hline 8.Potansiyelin Gerçekleştirilmesi & & & & & & & \\
\hline
\end{tabular}

$* * \mathrm{p}<.01 *$ Olumsuz duygular boyutuna ait maddeler ters puanlanmıştır.

Tablo 2 incelendiğinde örgütsel adalet ile örgütsel mutluluk ( $r=.50$ ve $\mathrm{p}<.01)$ arasında orta düzeyde ve anlamlı bir ilişki olduğu görülmektedir. Ayrıca örgütsel adalet ile örgütsel mutluluğun alt boyutlarından olumlu duygular $(\mathrm{r}=.51$ ve $\mathrm{p}<.01)$ arasında da yine yüksek düzeyli ve anlamlı bir ilişki vardır. Örgütsel adalet ile örgütsel mutluluğun alt boyutlarından olumsuz duygular $(r=.44$ ve $\mathrm{p}<.01)$ ve potansiyelin gerçekleştirilmesi $(r=.34$ ve $\mathrm{p}<.01)$ arasında ise orta düzeyde ve anlamlı bir ilişki bulunmaktadır.

Örgütsel adaletin alt boyutlarından dağıtımsal adalet ile örgütsel mutluluk ( $r=.48$ ve $\mathrm{p}<.01)$ arasında orta düzeyde ve anlamlı bir ilişki olduğu görülmektedir. Ayrıca dağıtımsal adalet ile örgütsel mutluluğun alt boyutlarından olumlu duygular $(\mathrm{r}=.49$ ve $\mathrm{p}<.01)$, olumsuz duygular $(\mathrm{r}=.42$ ve $\mathrm{p}<.01)$ ve potansiyelin gerçekleştirilmesi ( $r=.31$ ve $\mathrm{p}<.01)$ arasında orta düzeyde ve anlamlı bir ilişki bulunmaktadır.

Örgütsel adaletin alt boyutlarından işlemsel adalet ile örgütsel mutluluk $(r=.49$ ve $p<.01)$ arasında orta düzeyde ve anlamlı bir ilişki olduğu görülmektedir. Ayrıca işlemsel adalet ile örgütsel mutluluğun alt boyutlarından olumlu duygular $(\mathrm{r}=.50$ ve $\mathrm{p}<.01)$ arasında orta düzeyde ve anlamlı bir ilişki vardır. Yine işlemsel adalet ile örgütsel mutluluğun alt boyutlarından olumsuz duygular $(r=.43$ ve $p<.01)$ ve potansiyelin gerçekleştirilmesi $(r=.35$ ve $\mathrm{p}<.01)$ arasında ise orta düzeyde ve anlamlı bir ilişki bulunmaktadır.

Örgütsel adaletin alt boyutlarından etkileşimsel adalet ile örgütsel mutluluk $(r=.45$ ve $p<.01)$ arasında orta düzeyde ve anlamlı bir ilişki olduğu görülmektedir. Ayrıca etkileşimsel adalet ile örgütsel mutluluğun alt boyutlarından olumlu duygular $(\mathrm{r}=.45$ ve $\mathrm{p}<.01)$, olumsuz duygular $(\mathrm{r}=.40$ ve $\mathrm{p}<.01)$ ve potansiyelin gerçekleştirilmesi $(r=.30 \mathrm{ve} \mathrm{p}<.01)$ arasında orta düzeyde ve anlamlı bir ilişki bulunmaktadır. 
Örgütsel adalet ve alt boyutları değişkenlerinin örgütsel mutluluk değişkenini yordamasına ilişkin gerçekleştirilen basit doğrusal regresyon analizi sonuçları Tablo 3'te yer almaktadır.

Tablo 3. Örgütsel Adaletin Örgütsel Mutluluğu Yordamasina İlişkin Basit Regresyon Analiæi Sonuclarn

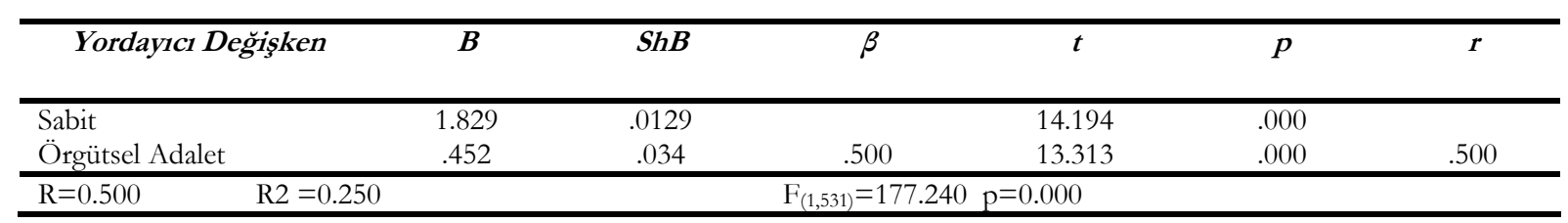

Yordanan değissken olan örgütsel mutluluk ile yordayıcı değişken olan örgütsel adalet arasındaki korelasyon katsayısı incelendiğinde örgütsel adalet ile örgütsel mutluluk arasında yüksek düzeyde olumlu bir ilişkinin $(\mathrm{r}=0.50)$ olduğu görülmektedir. Tablo 3’te görüldüğü gibi örgütsel adalet, örgütsel mutluluğun önemli bir yordayıcısıdır $(\mathrm{R}=0.500, \mathrm{R} 2=0.250, \mathrm{p}<.01)$. Örgütsel adalet, örgütsel mutluluğun \%25'ini açıklamaktadır. Örgütsel adaletin alt boyutlarının örgütsel mutluluğu yordamasına ilişkin çoklu doğrusal regresyon analizi sonuçları Tablo 4'de sunulmuştur.

Tablo 4. Örgütsel Adalet Alt Boyutlarnmn Örgütsel Mutluluğu Yordamasina İliskin Coklu Doğrusal Regresyon Analiæi Sonuclart

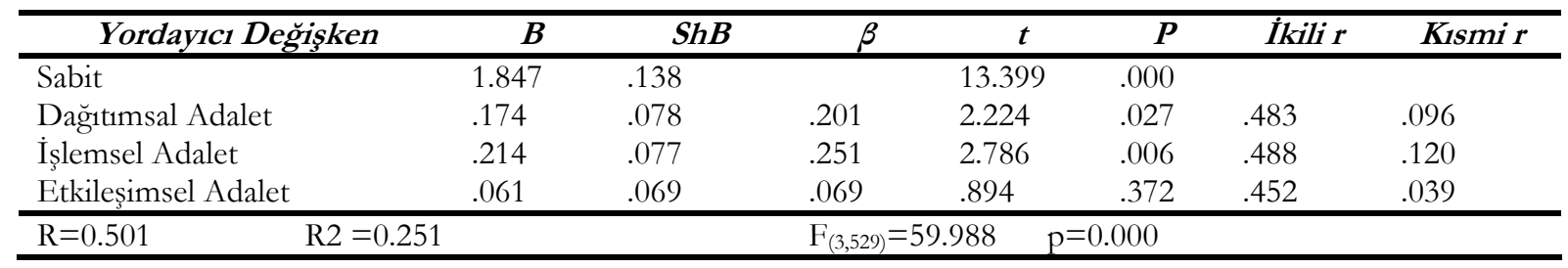

Tablo 4 incelendiğinde; örgütsel adaletin boyutlarının tamamının örgütsel mutluluğun yordayıcısı olduğu görülmektedir $(\mathrm{R}=0.501, \mathrm{R} 2=0.251, \mathrm{p}<.01)$. Örgütsel adaletin üç alt boyutu olan; dağttımsal adalet, işlemsel adalet ve etkileşimsel adalet örgütsel mutluluğun yaklaşık \%25'ini açıklamaktadır. Yordayıc1 değişken olan örgütsel adaletin alt boyutlarının örgütsel mutluluğu açıklamadaki önem sırası; işlemsel adalet $(\beta=0.251)$, dağttımsal adalet $(\beta=0.201)$ ve etkileşimsel adalet $(\beta=0.069)$ şeklindedir. Regresyon katsayılarının anlamlılı̆̆ına ilisskin değerler incelendiğinde adaletin üç boyutundan dağıtımsal adalet $(\mathrm{p}<$ $0.05)$ ve işlemsel adaletin $(\mathrm{p}<0.01)$ örgütsel mutluluğu anlamlı bir şekilde açıkladığ1 görülürken etkileşimsel adalet $(\mathrm{p}>0.05)$ örgütsel mutluluğu açıklamada etkili değildir. Yordayıcı değişkenlerle örgütsel mutluluk arasındaki ilişkilere bakıldığında; dağıtımsal adalet ile $(\mathrm{r}=0.483)$, [diğer yordayıcı değişkenlerin etkisi kontrol edildiğinde $(r=0.096)$ ], işlemsel adalet ile $(r=0.488)$, [diğer yordayıcı değişkenlerin etkisi kontrol edildiğinde $(r=0.120)]$, düzeyinde korelasyon gözlenmektedir.

Çoklu doğrusal regresyonda yordayıcı değişkenler birlikte analize katılmaktadır. Önceden analize alınan yordayıcı değiş̧kenleri kontrol ederek diğer yordayıcı değişkenlerin teker teker ya da modeller halinde analize sokulması için hiyerarşik regresyon analizi yapılmaktadır. Bu regresyon analizinde, daha önceki adımlarda analize giren yordayıcı değisskenler daha sonra analize girecek yordayıcı değiş̧kenler için kontrol değişkeni konumundadır (Büyüköztürk, 2018, s. 100). Örgütsel adalet alt boyutlarının örgütsel mutluluğu yordamasına ilişkin çoklu doğrusal hiyerarşik regresyon analizi sonuçları Tablo 5 'de sunulmuştur.

Tablo 5. Örgütsel Adalet Alt Boyutlarnnn Örgütsel Mutluluğu Yordamasına İlişkin Çoklu Doğgrusal Hiyerarşik Regresyon Analizi Sonuclar

\begin{tabular}{|c|c|c|c|c|c|c|}
\hline & $B$ & Standart Hata & $\bar{\beta}$ & $\bar{t}$ & $P$ & $\overline{\Delta R 2}$ \\
\hline Adim 1 & & & & & & $.239 * *$ \\
\hline İşlemsel Adalet & .417 & .032 & .488 & 12.899 & .000 & \\
\hline Adim 2 & & & & & & $.011 * *$ \\
\hline İşlemsel Adalet & .241 & .071 & .282 & 3.384 & .001 & \\
\hline Dağıtımsal Adalet & .201 & .072 & .232 & 2.781 & .006 & \\
\hline Adim 3 & & & & & & $-.001 * *$ \\
\hline İşlemsel Adalet & .214 & .077 & .251 & 2.786 & .006 & \\
\hline Dağıtımsal Adalet & .174 & .078 & .201 & 2.224 & .027 & \\
\hline Etkileşimsel Adalet & .061 & .069 & .069 & .894 & .372 & \\
\hline
\end{tabular}

$* * \mathrm{p}<0.01$ 
Analize ilk adımda, alt boyutlardan örgütsel mutluluk ile en yüksek ilişkiye sahip ( $r=.49)$ işlemsel adalet boyutu alınmıştır. İşlemsel adalet değişkeni örgütsel mutluluk değişkenine ait varyansın yaklaşık \%24'ünü açıklamaktadır. İşlemsel adalet ve örgütsel mutluluk arasında pozitif anlamlı bir ilişki vardır. Analize ikinci adımda dağıtımsal adalet değişkeni dâhil edilmiştir. İşlemsel adalet değişkeni kontrol edildiğinde dağitımsal adalet değişkeni örgütsel mutluluk değişkeninde daha önce açıklanan varyansa \%1.1 katkı sağladığ1 görülmektedir. Dağıtımsal adalet ve örgütsel mutluluk arasında pozitif anlamlı ilişki söz konusudur. İşlemsel adalet, dağıtımsal adalet ve etkileşimsel adalet değişkenleri kontrol edildiğinde ise, üçüncü adımda analize dâhil edilen etkileşimsel adaletin açıklanan varyansa anlamlı bir katkı sağlamadığı görülmektedir.

\section{Sonuç, Tartışma ve Öneriler}

Araştırma sonucunda, öğretmenlerin örgütsel adalet alg1 düzeyleri ile örgütsel mutluluk düzeyleri arasında anlamlı bir ilişki olduğu ve örgütsel adaletin, örgütsel mutluğu anlamlı biçimde yordadığı bulunmuştur. Öğretmenlerin örgütsel mutluluklarını anlamlı şekilde yordayan örgütsel adalet algisının okullarda artılmasının öğretmenlerin örgütsel mutluluklarına olumlu etkide bulunacağını ifade etmek mümkündür. Alan yazında ifade edildiği gibi (Greenberg ve Colquitt, 2005; Walumbwa, Peterson, Avolio ve Hartnell, 2010) adil bir şekilde davranılan işgörenlerin kendilerini daha iyi hissettikleri ve psikolojik sermayelerinde artış olduğu sonucusuda örgütsel mutluluk algısının artırılmasında örgütsel adaletin etkinin ne derece önemli olduğunu ortaya koymaktadır.

Çoklu regresyon analizinden elde edilen sonuçlar, örgütsel adaletin alt boyutları olan dağıtımsal adalet ve işlemsel adaletin, öğretmenlerin örgütsel mutluluk düzeylerini anlamlı biçimde yordadığını, etkileşimsel adaletin ise örgütsel mutluluğu anlamlı bir şekilde yordamadığını ifade etmektedir. Bu sonuç daha önce Behrani’nin (2017) ortaya koyduğu adaletin alt boyutlarından dağıtımsal adalet ile örgütsel mutluluk arasında ve Jandaghi vd. (2012) ulaştığı örgütsel adalet ile örgütsel mutluluk arasında olumlu ve anlamlı bir ilişki olduğu ifadelerini desteklemektedir. Yine işgörenlerin adalet algılarının psikolojik sermayeleri ve örgütsel mutlulukları üzerine etkisini ortaya koymak üzere yapılan diğer bir araştırmada (Çelik, Turunç ve Bilgin, 2014) örgütsel adalet boyutlarının (etkileşimsel, dağıtımsal ve işlemsel) işgörenlerin olumlu sermayelerini ve örgütsel mutluluk düzeylerini olumlu ve anlamlı bir şekilde etkilediği sonuçları ile paralellik göstermektedir. Etkileşimsel adaletin örgütsel mutluluğu yordamaması, işlemsel adalet ile arasındaki yüksek bağlantılılıktan kaynaklanabileceği gibi etkileşimsel adalet boyutunun örgütsel mutluluğu aracı değişken olarak diğer boyutlar üzerinden etkileme potansiyelinden de kaynaklı olabilir. Hiyerarşik regresyon analizi sonuçları incelendiğinde, örgütsel mutluluk ile dağıtımsal adalet ve örgütsel mutluluk ile işlemsel adalet arasındaki ilişkilerin düzeylerinin birbirlerine yakın olduğu görülmektedir. Bu durumun nedeni, dağıtımsal adalet ve işlemsel adaletin birbirlerinden farklı boyutlar olmasına rağmen kuramsal olarak birbirlerine benzerlikler göstermesi olabilir. Çünkü işlemsel adaletin, dağıtımsal adaletin ortaya çıkmasında ve sonrasında sürdürülebilmesinde ön şart olduğunu ifade etmek mümkündür (Halis ve Akova, 2008, s. 462). Bu noktada dağıtımsal adalet, örgüt içinde ödül ve ceza gibi yaptırımların adil bir şekilde dağıtılması anlamına gelirken (İşcan ve Naktiyok, 2004, s. 183), işlemsel adalet; işgörenler için büyük önem taşıyan terfi, ücret, performans değerlendirme ve çalışma şartları gibi konularla ilgili hususların tespitinde kullanılan yöntem ve politikaların adil olma derecesini ifade eder (Tan ve Çetin, 2011, s. 2). Ayrıca işlemsel adalet ile örgütsel mutluluk arasındaki ilişkinin, dağıtımsal adalet ile örgütsel mutluluk arasındaki ilişkiden yüksek çıkmasının nedeni; öğretmenlerin yatırımları neticesinde ortaya çıkan (ücret, terfi vb.) kazanımlardan daha çok bu kazanımların uygun ve adaletli bir şekilde paylaştırlması süreciyle ilgilenmeleri olabilir.

Araştırma sonuçlarından, örgütsel adalete ilişkin algının örgütsel mutluluğu yordadığı görülmektedir. Bu sonuçtan hareketle öğretmenlerin olumlu duyguları daha sık yaşamaları, olumsuz duyguları daha az hissetmeleri ve potansiyellerini daha güçlü bir şekilde gerçekleştirmeleri amacıyla adil örgütlerin tasarlanması önemlidir. Öğretmenlerin örgütsel mutluk düzeyleri arttırıldığında eğitim kademesinin her aşamasında bu mutlu olma durumu hissedilerek tüm paydaşlar aracilığıyla toplumun mutluluğuna katkıda bulunabileceğinden, yüksek örgütsel adalet düzeyin sürdürülmesine, daha yüksek düzeye çıkartılmasina yönelik politikalar geliştirilmesi önerilebilir.

Araştırmada örgütsel adaletin alt boyutlarından dağıtımsal adalete ilişkin algının örgütsel mutluluğu yordadığı görülmektedir. Bu sonuçtan hareketle okulların kazanımlarının adil bir şekilde dağıtılacağı algısına sahip öğretmen olmalarının sağlanması önemlidir. Bu amaç doğrultusunda; öğretmenlerin ders programları adil bir şekilde hazırlanması, öğretim yılı başında dersler zümre öğretmenlerine, ders dışı 
etkinlikler ise tüm öğretmenlere dengeli bir şekilde paylaştırlarak eşit sorumluluklar almalarının sağlanması önerilebilir. Yine yöneticilerin örgütsel kararları tarafsız bir şekilde alarak öğretmenlere ödüllerin adaletli bir şekilde dağıtılmasının sağlaması önerilebilir.

Araştırmada, örgütsel adaletin alt boyutlarından işlemsel adalete ilişkin algının örgütsel mutluluğu yordadığı görülmektedir. Bu açıdan bakıldığında öğretmenler için büyük önem taşıyan terfi, ücret, performans değerlendirme ve çalışma şartları gibi konularla ilgili hususların tespitinde kullanılan yöntem ve politikaların adil olmasının sağlanması, okullarda güven ortamı yaratılarak tüm paydaşlar arasında etkili bir iletişim kurulması önemlidir. Bu amaç doğrultusunda; yöneticilerin örgütsel kararlar almadan önce tüm ögretmenlerden tam ve doğru bilgiler toplayarak onların görüşlerini alması; aldıkları kararları, kararların sonuçlarını ve öğretmenler tarafindan talep edilmesi halinde kararların gerekçelerini ayrım yapmadan açı ve eksiksiz bir şekilde paylaşması önerilebilir. Yine yöneticilerin yasa, tüzük, yönetmelik, genelge vb. gibi mevzuat hükümlerini tüm öğretmenlere yansız ve tutarlı bir şekilde uygulaması önerilebilir.

Her araştırmanın olduğu gibi bu araştırmanında sınırlılıkları bulunmaktadır Araştırma, Kocaeli ili merkez İzmit ilçesinde bulunan 47 kamu ortaokulunda görev yapman 533 öğretmenle yürütülmüştür. Araştırma sonuçları örneklemin alındığı ilgili evrenle sınırlı olacak şekilde genellenebilir. Sonuçların değişik evren ve örneklemlerde sınanması için benzer araştırmalar; özel okullarda, başka şehirlerde, bölgelerde, ülkelerde, değişik öğretim kademelerinde yapılabilir. Ayrıca araştırma, ilişkisel tarama deseni ile gerçekleştirilen nicel bir araştırmadır. Veri çeşitliliğinin ortaya konulması amacıyla nitel veri toplama tekniklerinin de kullanıldığı karma desenli benzer araştırmalar tasarlanabilir. Bu araştırmada örgütsel adalet ve alt boyutları ile örgütsel mutluluk arasındaki ilişkiye odaklanılmış olup örgütsel mutluluğu yordayacağı düşünülen farklı değişkenler ile örgütsel mutluluk arasındaki ilişkiyi ortaya koymayı amaçlayan başka araştırmalar yapılabilir.

\section{Etik Beyan}

“Ortaokul Ögrretmenlerinin Örgütsel Adalet Algı Düzeyleri İle Örgütsel Mutluluk Düzeyleri Arasindaki İlişki” başlıklı çalısmanın yazım sürecinde bilimsel, etik ve alıntı kurallarına uyulmuş; toplanan veriler üzerinde herhangi bir tahrifat yapılmamış ve bu çalışma herhangi başka bir akademik yayın ortamına değerlendirme için gönderilmemiştir. Araştırmanın verileri 2018-2019 eğitim-öğretim yllında toplanmıştır. Bu araştırmanın verileri 01.01.2020 tarihinden önce toplandığ1 için etik kurul kararı zorunluluğu taşımamaktadır.

\section{Kaynakça}

Arslan, Y. (2018). Öğretmenlerin farkllhklarn yönetimi yaklaşmlarna iliskin alglan ile örgitsel mutluluk algular arasindaki iliski (Doktora Tezi). Kocaeli Üniversitesi Sosyal Bilimler Enstitüsü, Kocaeli.

Arslan, Y. ve Soner Polat (2018). Örgütsel mutluluk ölçeğinin Türkçeye uyarlanması. Kuram ve Uygulamada Eğitim Yönetimi Dergisi, 23(4), 603-622.

Bakker, A. B. ve Demerouti, E. (2013). Job demands-resources model. Revista de Psicologa del Trabajo y de las Organizaciones, 29(3), 107-115.

Barati, H., Arizi, H. R. ve Noory, A. (2009). The simple and multiple relationship between organizational justice and job performance in Isfahan Steel Mill Company. Management Perspective Journal, 33, 9-28.

Behrani, P. (2017). Organisational justice and employee happiness. International Journal of Research and Review, 4(7), 123129.

Beugre, C. D. ve Baron, R. A. (2001). Perceptions of systemic justice: The effects of distributive, procedural, and interactional justice. Journal of Applied Social Psychology, 31(2), 324-339.

Bies, R. J. ve Moag, J. S. (1986). Interactional justice: Communication criteria for fairness. In B. H. Sheppard (Eds), Research on Negotiation in Organizations (ss. 43-55). Greenwich: JAI Press.

Bradburn, N. M. (1969). The Structure of psychological well-Being. Oxford: Aldine.

Bradburn, N. M. ve Caplovitz, D. (1965). Reports on happiness: A pilot study of behavior related to mental health (No. 3). Aldine Pub. Co.

Bulut, A. (2015). Ortaögretim ögrretmenlerinin örgütsel mutluluk algilarmm incelenmesi: bir norm çalsşması (Doktora Tezi). Gaziantep Üniversitesi Eğitim Bilimleri Enstitüsü, Gaziantep.

Büyüköztürk, Ş. (2018). Sosyal bilimler iģin veri analiəi el kitabr (24. Baskı). Ankara: Pegem Akademi.

Büyüköztürk, S.., Kilıç-Çakmak, E., Akgün, Ö. E., Karadeniz, Ş. ve Demirel, F. (2016). Bilimsel araștrma yöntemleri. Ankara: Pegem Akademi.

Colquitt, J. ve Greenberg, J. (Eds.) (2005). Handbook of organizational justice. Lawrence Erlbaum Associates.

Colquitt, J. A., Conlon, D. E., Wesson, M. J., Porter, C. O. L. H ve Ng, K. Y. (2001), Justice at the millennium: A meta-analytic review of 25 years of organizational justice research. Journal of Applied Psybology, 86(3), 425-445. 
Cropanzano, R. ve Greenberg, J. (1997). Progress in organizational justice: Tunneling through the maze. In C. L. Cooper \& I. T.

Cropanzano, R., Ambrose, M. L., Greenberg, J. ve Cropanzano, R. (2001). Procedural and distributive justice are more similar than you think: A monistic perspective and a research agenda. Advances in Organizational Justice, 119, 151.

Cropanzano, R., Bowen, D. E. ve Gilliland, S. W. (2007). The management of organizational justice. Academy of Management Perspectives, 21(4), 34-48.

Csikszentmihalyi, M. (2005). Akıs, mutluluk bilimi. Ankara: HYB Basın Yayım.

Çelik, M., Turunç,Ö. ve Bilgin, N. (2014). İsgörenlerin örgütsel adalet algılarının psikolojik sermaye üzerine etkisi: İşgörenlerın iyilik halinin düzenleyici rolü. Dokuz. Eylül Üniversitesi Sosyal Bilimler Enstitüsü Dergisi, 16(4), 559-585.

Daniels, K. (2000). Measures of five aspects of affective well-being at work. Human Relations, 53(2), 275-294.

Demirel, Y. ve Seçkin, Z. (2011), Örgütsel adaletin bilgi paylaşımı üzerine etkisi: ilaç sektörü çalışanlarına yönelik bir araştırma. Bilig, 56, 99-119.

Diener, E. (1984). Subjective well-being. Psychological Buletin, 95(3), 542-575.

Diener, E. (2000). Subjective well-being: The science of happiness and a proposal for a national index. American Psychologist, 55(1), 34-43.

Eren, E. (2000). Örgütsel davranış ve yönetim psikolojisi. Yenilenmiş VI. Baskı. İstanbul: Beta Basım Yayın Dağıtım.

Field, A. (2013). Discovering statistics using IBM SPSS statistics. London: Sage.

Fisher, C. D. (2010). Happiness at work. International Journal of Management Reviews, 12(4), 384-412.

Frey, B. ve Stutzer, A. (2001). Happiness and economics: How the economy and institutions affect human well-being. New Jersey: Princeton University Press.

Gavin, J. H. ve Mason, R. O. (2004). The virtuous organization: The value of happiness in the workplace. Organizational Dynamics, 33(4), 379-392

Golparvar, M. ve Abedini, H. (2014). Relationship between meaning and spirituality at work with job happiness positive affect and job satisfaction. Management Science Letters, 4, 255-268.

Grant, A. M. ve Campbell, E. M. (2007). Doing harm doing good, being well and burning out: The interactions of perceived prosocial and antisocial impact in service work. Journal of Occupational and Organizational Psychology, 80, 665- 691.

Greenberg, J. (1996). The quest for justice on the job, essays and experiments. Thousand Oaks, CA, Sage.

Greenberg, J. ve Colquitt, J. A. (2005). Handbook of organizational justice. NJ: Erlbaum.

Halis, M. ve Akova, O. (2008). Turizm işletmelerinde örgütsel adalet. İçinde F. Okumuş ve U. Avc1 (Eds.) Turiz̧m işletmelerinde çă̆das yönetim teknikleri. Ankara: Detay Yayıncıllk.

İçerli, L. (2010). Örgütsel adalet: kuramsal bir yaklaşım. Girişimcilike ve Kalkınma Dergisi, 5(1), 67-92.

İşcan, Ö. F. ve Sayın, U. (2010). Örgütsel adalet, iş tatmini ve örgütsel güven arasındaki ilişki. Atatürk Üniversitesi İktisadi ve İdari Bilimler Dergisi, 24(4), 195-216.

İşcan, Ö. F. ve Naktiyok, A. (2004). İşgörenlerin örgütsel bağdaşımlarının belirleyicileri olarak örgütsel bağlılık ve örgütsel adalet alg1lar1. Ankara Üniversitesi Siyasal Bilgiler Fakültesi Dergisi, 59(1), 181-201.

Jandaghi, G., Alimadadi, A., Fard, S. M. H. ve Golverdi, M. (2012). Relationship between organizational justice and staff happiness in the institutes of standard and industrial research of Qom province and jihad agricultural management in Qom city. Human Resource Management, 43, 6618-6626.

Kashdan, T. B., Biswas-Diener, R. ve King, L. A. (2008). Reconsidering happiness: The costs of distinguishing between hedonics and eudaimonia. Journal of Positive Psychology, 3, 219-233.

Lind E. A. ve Tyler T. R.(1988). The social psychology of procedural justice. New York: Plenum.

Masterson, S. S., Lewis, K., Goldman, B. M. ve Taylor, M. S. (2000). Integrating justice and social exchange: The differing effects of fair procedures and treatment on work relationships. Academy of Management Journal, 43, 738748.

Neugarten, B. L., Havighurst, R. J. ve Tobin, S. S. (1961). The measurement of life satisfaction. Journal of Gerontology, 16, 134-143.

Özmen, Ö. N. T., Arbak, Y. ve Özer P. S. (2007). An inquiry about the effect of justice value on justice perception. Ege Akademik Bakıș Dergisi, 7(1), 19-35.

Polat, S. (2007). Ortä̈gretim ögrretmenlerinin örgütsel adalet algilar, örgütsel güven düzeyleri ile örgütsel vatandaşlhk davranışlar arasındaki ilişki (Doktora Tezi). Kocaeli Üniversitesi Sosyal Bilimler Enstitüsü, Kocaeli.

Pryce-Jones, J. (2011). Happiness at work: Maximizing your psychological capital for success. John Wiley \& Sons.

Rani, N., Yadav, S. S ve Jain, P. K. (2012). Impact of mergers and acquisitions on returns to shareholders of acquiring firms: Indian economy in perspective. Journal of Financial Management and Analysis, 25(1).

Tan, Ö. ve Çetin, C. (2012). Performans değerlendirme sistemine ilişkin örgütsel adalet algısının sistemden duyulan memnuniyet üzerindeki etkisini belirlemeye yönelik bir araştırma. Öneri Dergisi, 9(35), 1-13.

Tezcan Uysal, H. ve Aydemir, S. (2014). Örgütsel iklimin çalışma psikolojisine etkisi: Sağlık sektöründe bir araştırma. Electronic Turkish Studies, 9(2), 1557-1574.

Walumbwa, F. O., Peterson, S. J., Avolio, B. J. ve Hartnell, C. A. (2010). An investigation of the relationships among leader and follower psychological capital, service climate, and job performance. Personnel Psychology, 63(4), 937963.

Warr, P. (2011). Work, happiness, and unhappiness. NJ: Psychology Press. 
Waterman, A. S. (1993). Two conceptions of happiness: Contrasts of personal expressiveness (eudaimonia) and hedonic enjoyment. Journal of Personality and Social Psychology, 64(4), 678-691.

What Works Centre for Wellbeing. (2017b). Good work, wellbeing and performance. https://www.whatworkswellbeing.org/product/good-work-wellbeing-and-changes-in performance-outcomes/ adresinden 14.01.2018 tarihinde elde edilmiştir.

Yaghubi, M., Saghaeian Esfahani, S., Abolghasem Gorgi, H., Norouzi, M. ve Rezaei, F. (2009). The relationship between organzizationl justice and job satisfaction among the employees of selected hospitals of Isfahan University of Medical Sciences. Journal of Scientific Research of Health Management, 12(35), 25-32.

Yazıcıoğlu, Y. ve Erdoğan, S. (2004). SPSS uygulamalı bilimsel araştırma yöntemleri. Ankara: Detay Yayıncılık.

Yeniçeri, Ö., Demirel, Y. ve Seçkin, Z. (2009). Örgütsel adalet ile duygusal tükenmişlik arasındaki ilişki: İmalat sanayi çalışanları üzerine bir araştırma. Karamanoğlu Mehmetbey Üniversitesi Sosyal ve Ekonomike Araştırmalar Dergisi, 2009(1), 83-99.

\section{EXTENDED ABSTRACT}

Studies show that being happy, feeling good and living a pleasant life provides many advantages to the individual and the organization of which the individual is a part. Since schools are organizations where social transformation begins, any change that will affect the school, which is one of the sub-systems of the society, also affects society. Undoubtedly, the happiness of the teachers who are the employees of the school organizations will contribute to the happiness of the students.

Employees take their existing knowledge and experience as the capital when they join an organization. By starting to use this capital in the name of the interests of the organization over time, they try to turn their labor into an investment for their individual benefits and desire to provide equal output (wage, promotion, recognition, etc.) at the rate of benefit they give to the organization. They then compare their own gains with the gains of other employees, taking the outputs obtained as a benchmark for themselves. While making this comparison, they make some fairness evaluations on their own. This comparison creates the perception of individuals as to whether they are treated fairly within the organization. Individuals with a high perception of justice will contribute to the organization's transformation into a healthy working environment and the realization of organizational activities more effectively. This study focuses on the relationship between teachers' perception levels of organizational justice and its sub-dimensions and organizational happiness levels.

In this study, it is aimed to reveal the relationship between secondary school teachers' organizational justice perception levels and organizational happiness levels. The relational screening model was used in the research. The universe of the study consists of teachers in secondary schools in Izmit District Center of Kocaeli Province. The sample of the study consists of 533 teachers working in General Secondary Schools and Religious Secondary Schools in Izmit district of Kocaeli province in the academic year of 2018-2019. As data collection tools, the "Organizational Justice Scale" developed by Niehoff and Moorman and adapted to Turkish by Polat (2007) and the "Organizational Happiness Scale" developed by Paschoal and Tamayo and adapted into Turkish by Arslan and Polat (2018) were used. In the analysis of the data, the Pearson correlation coefficient was calculated for the correlation between variables, and to examine the predictive power of the predictive variables on the predicted variable, first simple linear regression analysis, then multiple linear and multiple hierarchical regression analyzes were performed.

As a result of the research, it was found that there is a high level and significant relationship between organizational justice and organizational happiness $(r=.50$ and $\mathrm{p}<.01)$. In addition, there is a high level and significant relationship between organizational justice and positive emotions $(\mathrm{r}=.51$ and $\mathrm{p}<.01)$, which is one of the sub-dimensions of organizational happiness. A moderate and significant relationship was found between organizational justice and negative emotions $(r=.44$ and $p<.01)$ and realization of potential $(\mathrm{r}=.34$ and $\mathrm{p}<.01)$, which are sub-dimensions of organizational happiness.

It is seen that there is a moderate and significant relationship between distributive justice, which is a sub-dimension of organizational justice, and organizational happiness $(r=.48$ and $p<.01)$. Also, a moderate and significant relationship was found between distributive justice and positive emotions $(\mathrm{r}=$ .49 and $\mathrm{p}<.01)$, negative emotions $(\mathrm{r}=.42$ and $\mathrm{p}<.01)$, and realization of potential $(\mathrm{r}=.31$ and $\mathrm{p}<.01)$ which are the sub-dimensions of and organizational happiness, and between

It is found that there is a moderate and significant relationship between organizational happiness and operational justice $(r=.49$ and $p<.01)$, which is one of the sub-dimensions of organizational justice. In addition, there is a high level and significant relationship between operational justice and positive 
emotions $(\mathrm{r}=.50$ and $\mathrm{p}<.01)$, which is one of the sub-dimensions of organizational happiness. A moderate and significant relationship was found between procedural justice and negative emotions $(\mathrm{r}=$ .43 and $\mathrm{p}<.01)$ and realization of potential $(\mathrm{r}=.35$ and $\mathrm{p}<.01)$, which are sub-dimensions of organizational happiness.

It has been observed that there is a moderate and significant relationship between organizational happiness and interactional justice $(\mathrm{r}=.45$ and $\mathrm{p}<.01)$, which are sub-dimensions of organizational justice. A moderate and significant relationship was found between interactional justice and positive emotions $(\mathrm{r}=.45$ and $\mathrm{p}<.01)$, negative emotions $(\mathrm{r}=.40$ and $\mathrm{p}<.01)$ and realization of potential $(\mathrm{r}=.30$ and $\mathrm{p}<.01)$, which are sub-dimensions of organizational happiness.

Organizational justice is an important predictor of organizational happiness $(R=0.500, R 2=0.250$, $\mathrm{p}<.01)$. Organizational justice explains $25 \%$ of organizational happiness. Another finding of the study is that all dimensions of organizational justice are predictors of organizational happiness $(\mathrm{R}=0.501, \mathrm{R} 2=$ $0.251, \mathrm{p}<.01)$. The three sub-dimensions of organizational justice, distributive justice, procedural justice, and interactional justice explain approximately $25 \%$ of organizational happiness. The order of importance of the sub-dimensions of organizational justice, which is the predictor variable, in explaining organizational happiness is procedural justice $(\beta=0.251)$, distributive justice $(=0.201)$, and interactional justice $(\beta=0.069)$. When the values related to the significance of the regression coefficients are examined, it is seen that distributive justice $(p<0.05)$ and procedural justice $(p<0.01)$, which are among the three dimensions of justice, explain organizational happiness significantly, whereas interactional justice ( $p>$ 0.05), which is also another dimension of justice, is not effective in explaining organizational happiness.

As a result of the research, it was found that there is a significant relationship between teachers' organizational justice perception levels and organizational happiness levels and organizational justice significantly predicts organizational happiness. It is possible to state that increasing the perception of organizational justice that significantly predicts teachers 'organizational happiness in schools will have a positive effect on teachers' organizational happiness. As stated in the literature (Greenberg \& Colquitt, 2005; Walumbwa, Peterson, Avolio, \& Hartnell, 2010), it is revealed that employees who are treated fairly feel better and their psychological capital increases, and as a result, the effect of organizational justice is important in increasing the perception of organizational happiness.

As a result of the research, it is seen that the perception of organizational justice predicts organizational happiness. Based on this result, it is important to design fair organizations in order for teachers to experience positive emotions more frequently, to feel negative emotions less, and to realize their potential more strongly. When the organizational happiness level of teachers is increased, it can be suggested to develop policies to maintain the high level of organizational justice and to increase it to a higher level, since this happiness can be felt at every stage of the education level and can contribute to the happiness of the society through all stakeholders. 